\title{
Erratum to: Baseline insulin sensitivity affects response to high-amylose maize resistant starch in women: a randomized, controlled trial
}

\author{
Barbara A. Gower ${ }^{1 *}$, Richard Bergman ${ }^{2}$, Darko Stefanovski ${ }^{3}$, Betty Darnell ${ }^{4}$, Fernando Ovalle $^{5}$, Gordon Fisher $^{6}$, \\ S. Katherine Sweatt', Holly S. Resuehr ${ }^{7}$ and Christine Pelkman ${ }^{8}$
}

After corrections were submitted for this article [1], the authors realised the clinical trials registry number which they provided was incorrect and was therefore published incorrectly in the article [1] as NCT0152806. The correct clinical trials registry number is: NCT01521806. This has also been updated in the original article [1].

\begin{abstract}
Author details
'Department of Nutrition Sciences, University of Alabama at Birmingham (UAB), 616A Webb Building, 1675 University Blvd, Birmingham, AL 35294, USA. ${ }^{2}$ Cedars-Sinai Diabetes and Obesity Research Institute, Los Angeles, CA, USA. ${ }^{3} \mathrm{New}$ Bolton Center, School of Veterinary Medicine, University of Pennsylvania, Philadelphia, PA 19104, USA. ${ }^{4}$ Clinical Research Unit, UAB, Birmingham, USA. ${ }^{5}$ Department of Medicine, Division of Diabetes, Endocrinology, and Metabolism, UAB, Birmingham, USA. ${ }^{6}$ Department of Human Studies, UAB, Birmingham, USA. ${ }^{7}$ Department of Nutrition Sciences, UAB, Birmingham, USA. Ingredion, Incorporated, Bridgewater, NJ, USA.
\end{abstract}

Received: 24 January 2016 Accepted: 24 January 2016

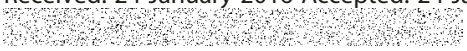

\section{Reference}

1. Gower BA, Bergman R, Stefanovski D, Darnell B, Ovalle F, Fisher G, et al. Baseline insulin sensitivity affects response to high-amylose maize resistant starch in women: a randomized, controlled trial. Nutr Metab. 2016;13:2. doi:10.1186/s12986-016-0062-5.

\footnotetext{
* Correspondence: bgower@uab.edu

'Department of Nutrition Sciences, University of Alabama at Birmingham (UAB), 616A Webb Building, 1675 University Blvd, Birmingham, AL 35294, USA
}

Submit your next manuscript to BioMed Central and we will help you at every step:

- We accept pre-submission inquiries

- Our selector tool helps you to find the most relevant journal

- We provide round the clock customer support

- Convenient online submission

- Thorough peer review

- Inclusion in PubMed and all major indexing services

- Maximum visibility for your research

Submit your manuscript at www.biomedcentral.com/submit
() Biomed Central 